\title{
Performance of Grid-Connected Rooftop Solar PV System for Households during Covid-19 Pandemic
}

\author{
Partaonan Harahap ${ }^{* 1}$, Faisal Irsan Pasaribu ${ }^{1}$, Chandra A. Siregar ${ }^{2}$, Benny Oktrialdi ${ }^{1}$ \\ ${ }^{1}$ Department of Electrical Engineering, Faculty of Engineering, \\ Universitas Muhammadiyah Sumatera Utara \\ Street Muchtar Basri No.3, Phone/fax 061-6624567/061-6625474, Medan, North Sumatra, Indonesia \\ ${ }^{2}$ Department of Mechanical Engineering, Faculty of Engineering, \\ Universitas Muhammadiyah Sumatera Utara \\ Street Muchtar Basri No.3, Phone/fax 061-6624567/061-6625474, Medan, North Sumatra, Indonesia \\ *Corresponding author e-mail: partaonanharahap@umsu.ac.id
}

\begin{abstract}
As we know, the need for electrical energy is increasing along with population growth and technological developments. This increase was also triggered by the growth rate of the energy demand of $6.86 \%$ per year. Most of the energy needs come from non-renewable energy, which has limitations and is not environmentally friendly. Despite being affected by Covid, this period is a momentum to start the direction of clean energy policies. The utilization of solar power can be started by utilizing a rooftop solar power system on the roof of a hotel or on the roof of other industrial buildings. As one of the research and development institutions in the housing and settlement infrastructure sector, it tries to provide alternative technology solutions through an innovative technology called PV-roof. The results of the research show that the designed roof offgrid has an average voltage and current on the first day of 13 Volts and a current of 1.8 $A$, and on the second day, 12.4 Volts and a current of $1.6 \mathrm{~A}$, while on the third day, 12.8 Volts and current of $1.8 \mathrm{~A}$. If the use of 1 battery bears a load of 450 Watts for 2.7 hours, then for users less than 5 hours, the solar charger controller capacity is $12.12 \mathrm{~A}$.
\end{abstract}

Keywords: PV-roof off grid, average voltage and current, battery, solar charger

\section{Introduction}

Renewable energy is an alternative energy source that is used as a substitute for fossil energy sources and petroleum. One example of a renewable energy source is solar energy. Solar power generation is environmentally friendly, and very promising. As an alternative to turn on power plants using steam (with oil and coal). Technological developments in making solar panels that are better than the level of efficiency, manufacture of durable batteries, and manufacture of electronic devices that can use Direct Current. At this time the use of solar power (solar cell panels) is still considered expensive because of the absence of subsidies. The electricity we use today is actually subsidized electricity. Imagine the exploitation/mining of kerosene, coal (which destroys the environment), the manufacture of steam power plants, distribution of electricity, all of which were built at a large cost[1]. Indonesia is a country that has a fairly high intensity of solar radiation, reaching $4,500 \mathrm{Wh} / \mathrm{m}^{2}[2]$.

Roof top solar panels are SPV panels that are installed above the house with the aim of generating electrical energy, so that it can reduce the use of electric power from PLN and does not even depend on the PLN network. Roof top solar panels can be connected to the PLN network (on grid system) or standalone (off grid system). Currently, almost all residential houses use energy sources from the PLN network. The source of electrical energy provided by PLN is as much as possible to save electricity consumption. One of the methods used is that every house uses a roof top solar panel, this aims to reduce dependence on energy sources from PLN. 
This PLTS system for residential purposes uses the Off Grid concept (independent of the PLN network) with batteries as energy storage for power supply at night. However, the inverter used is a type of Bi-directional Inverter so that electricity from the PLN network can be a backup if the energy from the PLTS stored in the battery does not meet the electricity needs of the house.

This can happen when the weather is cloudy for days so that no solar energy is absorbed into the PLTS system. The use of PLTS Rooftop Off Grid Solar Energy Accelerates Amid the Covid-19 Pandemic to be Implemented in Residential Homes, aiming to supply electricity and educational facilities for renewable energy that are very environmentally friendly Considering that Indonesia is a tropical area, it is very good if PLTS is developed seriously. Because PLTS is a form of long-term investment, coupled with cheap PLTS maintenance costs, it will be profitable for consumers of electrical energy.

In this study, Rooftop Solar Electricity (LSA) or Rooftop is the use of solar power plants on the roofs of houses/buildings belonging to everyone and operated in parallel with the electricity source from PLN as the consumer. As we know that the Government strongly encourages the use of this roof, by stipulating it in the Minister of Energy and Mineral Resources Regulation No. 49/2018. Rooftop also aims to save PLN electricity bills and encourage the use of renewable energy, clean and environmentally friendly energy and help the State realize national energy security while reducing the burden on the Government in reducing the balance of payments deficit due to fuel imports.

The use of Rooftop is a hero of development and wise in managing energy for the survival of our children and grandchildren. Reducing the use of fossil fuel energy is smart and very noble considering that Indonesia's fossil fuels will soon run out. Based on the Rooftop PLTS development policy contained in Presidential Regulation No.22/2017 concerning RUEN, one of the points is that industrial consumers can install and build Rooftop PLTS.

\section{Literature Study}

Rooftop PV System is a photovoltaic system that utilizes the roof of a house or the top cover of a commercial building for the location of installing solar panels. This system is smaller and compact compared to the installation of Ground-Mounted $\mathrm{Pv}$ systems such as LTS in general. The installation of rooftop panels is also getting easier and cheaper in line with the current technological developments.

The use of solar power as a source of electricity is quite commonly heard by the public as PLTS. However, because the socialization of new and renewable energy is still not optimal, there are still many who do not know that each PLTS has various kinds of differences. This PLTS difference is not based on the purpose and function of solar panels in everyday life. Not all solar panel systems will suit your electricity needs. Each solar panel system has a maximum electrical power that can be borne, it does not necessarily apply to the price of 5000 watt solar electricity. For household use, there are two systems that can be applied. These systems are called Solar Home System (SHS) and Solar PV Rooftop. So what distinguishes the two? Solar Home System (SHS) is a stand-alone power generation system, suitable for home needs such as lighting, computers and water pipes. SHS systems can be combined with backup sources such as generators with automatic switching systems. SHS is designed to be portable so that it is easy to move and adapt to user needs. SHS is a solution to overcome the electricity crisis in areas that have not been reached by the PLN electricity network.

Although by definition this system is PLTS, which means it can be used massively and spread out. However, this system is designed as a smallscale power plant with a maximum power of 100 $\mathrm{Wp}$ or daily energy production of about $>400 \mathrm{Wh}$ per solar panel[3].

\section{II.Relevant Literature Review}

One of the methods used is that each house uses a Roof top solar photovoltaic panel, this aims to reduce dependence on energy sources from PLN. The design is intended for the Solar Home System (SHS) or residential houses with reference to solar radiation in the Central Java region. The rooftop off grid solar photovoltaic system is designed using SPV panels, batteries, inverters and charge controller components. The designed power capacity is $1,576,2$ Watt and energy consumption per day is $4,260 \mathrm{Wh}$. The number of batteries is 12 units with a capacity of 310 Ah each, 6 units of SPV panels with a capacity of $225 \mathrm{Wp}, 1$ unit of inverter of 1000 Watts and 1 unit of charge controller of $40 \mathrm{~A}$. The angle of inclination is 16 degrees. The estimated investment cost incurred is Rp. 62,000,000,- [4]. 
Performance assessment of rooftop solar systems in various parts of Thailand using simulated PSIM. Comparison of solar roof installations in various areas was carried out to evaluate suitable locations. In addition, three types of solar panels are used in research: monocrystalline, polycrystalline, and thin film.

Furthermore, the economic evaluation of different sizes of rooftop solar systems using monocrystalline modules was investigated using the economic indicators of discounted payback period (DPP), net present value (NPV), internal rate of return (IRR), and profitability index (PI). The results show that the central region of Thailand is a suitable place for installing solar roofs in terms of solar radiation, and its temperature has more solar power generation capacity than other regions. Monocrystalline and polycrystalline solar panels can produce maximum power close to each other. All solar roof sizes with Feed-in Tariff (FiT) Scheme provide the same DPP 6.1 years, IRR $15 \%$, and PI 2.57 which is better than the case without FiT scheme. However, largescale solar roof system installations can receive more electrical energy generated from the solar roof system. As a result, larger size solar roof systems can achieve better economic satisfaction[5],[6].

Performance simulation of $5 \mathrm{~kW}$ rooftop solar PV system with Crystal solar cells. During this study, $15 \%$ efficient glass enclosed crystalline solar modules with a power temperature coefficient due $-0.47 \% /{ }^{\circ} \mathrm{C}$ were chosen. The PV system installed at an angle close to latitude was simulated using the PV Watts tool from the National Renewable Energy Laboratory (NREL). The results show the $5 \mathrm{~kW}$ PV system produces an annual energy of $7658 \mathrm{Wh}$ with a capacity factor of $17.5 \%$.[7] The value of energy costs for output production is also estimated to be around Rs. 34457. This study helps to understand how crystalline solar cells perform under the weather conditions of the Coimbatore location in India. [8] Indonesia's geographical conditions, which consist of: thousands of islands and archipelagos, scattered and uneven electrical load centers, low level of electricity demand in some areas, high marginal cost construction of an electrical energy supply system, and limited financial capacity, are inhibiting factors supply of electrical energy on a scale national.

Indonesia especially for West Kalimantan area is still a lot areas where there is no network electricity, therefore the use of sources
This solar energy is the usual used as an alternative energy source. Problems in energy utilization sun lies in the weather factor and alternation of day and night, so that the acquisition of solar energy into limited electrical energy in the supply. To change energy the sun into electrical energy is necessary known load usage load for designing and manufacturing SHS. Then in the presence of SHS which has stability and controllability is expected to be supply electrical energy according to usage load. From the results of the discussion, it can be seen that the efficiency of SHS This is based on measurements for 5 days 60 hours with each per day measurements were carried out for 12 hours. Obtained $15 \%$ solar module efficiency and solar charge controller efficiency $16 \%$ [9],[10].

\section{Research Method}

This research utilized several stages, as follows: The variables observed were load requirements, number of SPV panels, SPV panel capacity, charge controller capacity, battery capacity, battery capacity, conductors and safety, as well as cost calculations with reference prices at the time of research.

\section{III.1 Research stages}

In this study, the first step is to analyze the needs in accordance with field conditions by making observations, analyzing the total daily load used and evaluating the daily load (Watt) and Energy (Wh) data per day. This will be used to determine the capacity and number of solar panels with the aim of Performing an energy demand analysis, then designing a rooftop off grid Solar Photovoltaic and assembling hardware such as solar panel installations and power data monitoring devices.

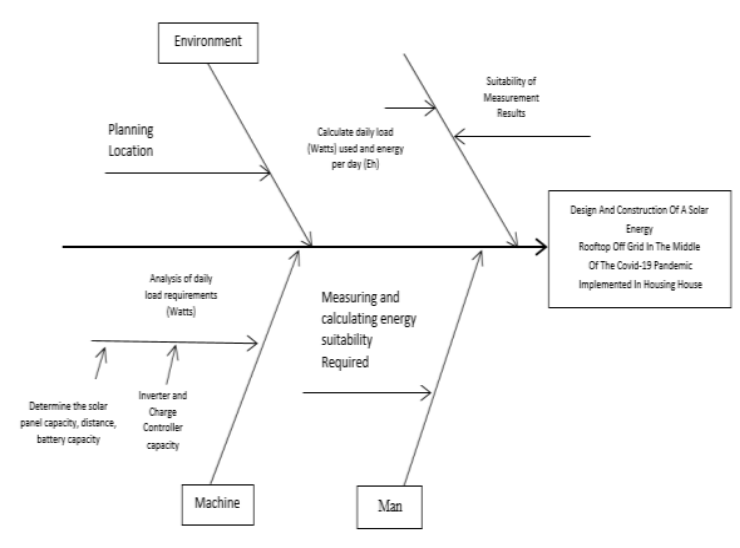

Fig 1. Fishbone Diagram problem analysis 


\section{2 Machine}

The hardware determines the solar panel capacity, distance, battery capacity, inverter capacity and charge controller. In addition, hardware maintenance in PV power plant is also very important in monitoring power plant performance data for the sustainability of generating units, so that periodic monitoring of generating units and supporting devices is required. Like a battery, suboptimal battery usage will shorten the battery life so that battery usage must be maintained so that the charging does not exceed the capacity and keep the battery capacity not below the minimum capacity.

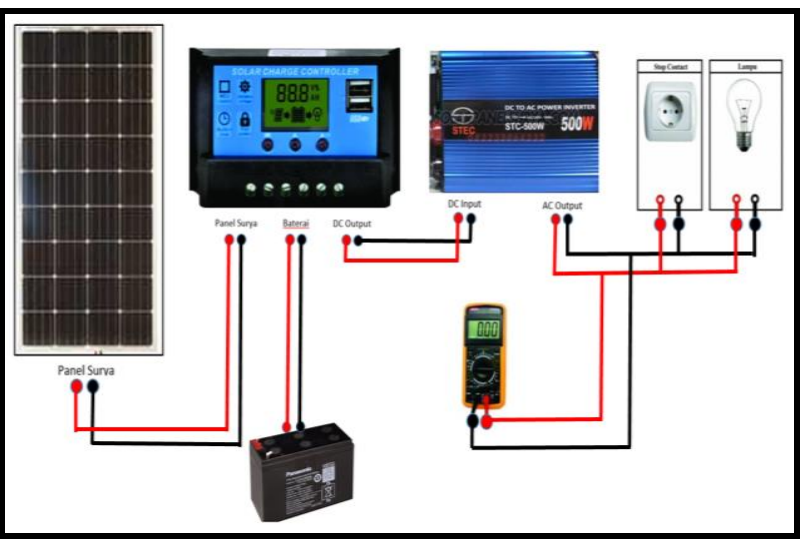

Fig 2. Circuit Schematic

\section{III.3 Method}

In collecting power plant performance data, the operator must visit the generator location. And also data collection of current and voltage values at the generator is still done manually using a multimeter measuring instrument. So it is not efficient in retrieving generator performance data if you still use manual methods like this.

\section{III.4 Man}

Manual monitoring has a weakness where the parameters and monitoring data obtained are very limited, incomplete and discontinuous due to operator limitations. As a monitoring operator, if observations are made locally with generating units located in scattered locations, the operator must visit the location of the generating unit so that it will waste time in the monitoring process due to operator limitations. The results of monitoring were carried out for 3 hours, as shown in the table below Table 1. Data on Current and Voltage Test Results on $100 \mathrm{Wp}$ Solar Panels.

\section{Results and Discussion}

This test was carried out after the installation of PLTS Rooftop Off Grid by measuring the panel surface temperature $(\mathrm{Tp}) 100 \mathrm{Wp}$. This is very necessary to do because it affects the usage load, current and voltage at the solar power plant is to determine the output power generated by solar cells.

TABLE 1

CurRent and Voltage Test Results Data On $100 \mathrm{WP}$ SOLAR PANELS ON THE FIRST DAY

\begin{tabular}{ccccc}
\hline $\begin{array}{c}\text { Day } \\
\text { Weather }\end{array}$ & $\begin{array}{c}\text { Time } \\
\text { Test }\end{array}$ & $\begin{array}{c}\text { Temper } \\
\text { ature } \\
\text { Conditions }\end{array}$ & $\begin{array}{c}\text { V Solar } \\
\text { Cells } \\
\text { (Volts) }\end{array}$ & $\begin{array}{c}\text { I Solar } \\
\text { Cell } \\
\text { (Ampere) }\end{array}$ \\
\hline The first & 09.00 & 41 & 13.99 & 1.92 \\
day / & 11.00 & 39 & 12.51 & 1,89 \\
scorching & 13.00 & 44 & 14 & 1,85 \\
& 15.00 & 38 & 11.85 & 1.6 \\
\hline
\end{tabular}

The solar panel test data on the first day was carried out for 5 hours with an average voltage of 13 Volts and a current of $1.8 \mathrm{~A}$.

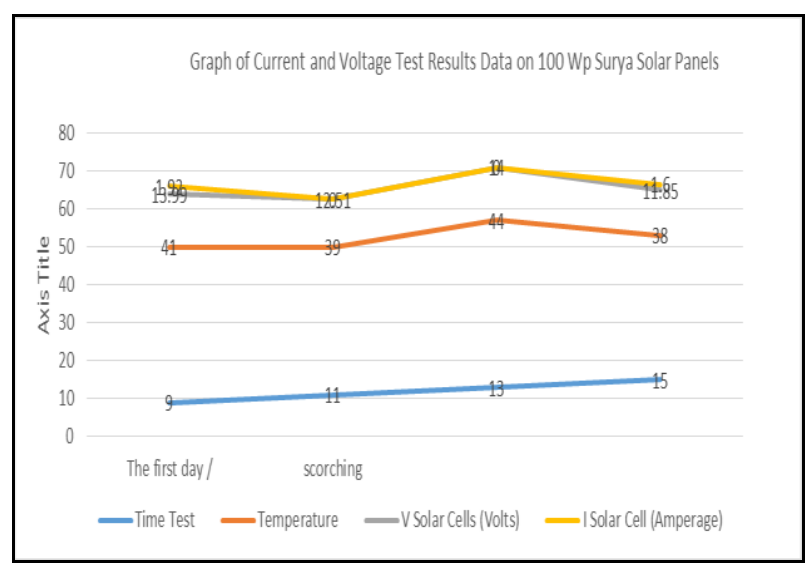

Fig 3. Graph of current and voltage measurement results on solar panel rooftops on the first day

TABLE 2

Data of CurRent AND Voltage Test Results on 100 WP SOLAR PANELS ON THE SECOND DAY

\begin{tabular}{ccccc}
$\begin{array}{c}\text { Day } \\
\text { Weather }\end{array}$ & $\begin{array}{c}\text { Time } \\
\text { Test }\end{array}$ & $\begin{array}{c}\text { Temper } \\
\text { ature } \\
\text { Conditions }\end{array}$ & $\begin{array}{c}\text { V Solar } \\
\text { Cells } \\
\text { (Volts) }\end{array}$ & $\begin{array}{c}\text { I Solar } \\
\text { Cell } \\
\text { (Amper) }\end{array}$ \\
\hline The second & 09.00 & 31 & 12.45 & $1, .2$ \\
day / & 11.00 & 39 & 12.51 & 1.89 \\
Cloudy & 13.00 & 40 & 13.1 & 1.81 \\
& 15.00 & 37 & 11.65 & 1.5 \\
\hline
\end{tabular}

The solar panel test data on the second day was carried out for 5 hours with an average voltage of 12,4 Volts and a current of 1.6A. 


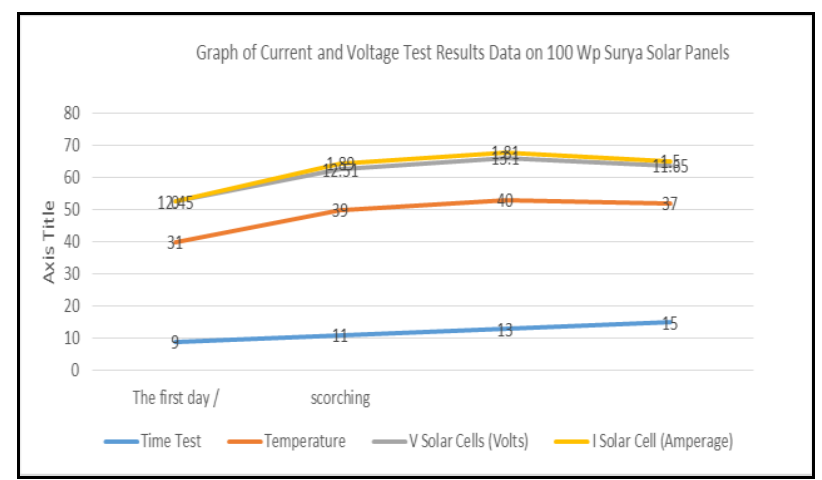

Fig 4. Graph of current and voltage measurement results on solar panel rooftops on the second day

TABLE 3

Data of Current and Voltage Test Results on $100 \mathrm{WP}$ SOLAR PANELS ON THE THIRD DAY

\begin{tabular}{ccccc}
\hline $\begin{array}{c}\text { Day } \\
\text { Weather }\end{array}$ & $\begin{array}{c}\text { Time } \\
\text { Test }\end{array}$ & $\begin{array}{c}\text { Tempe- } \\
\text { rature }\end{array}$ & $\begin{array}{c}\text { V Solar } \\
\text { Cells } \\
\text { (Volts) }\end{array}$ & $\begin{array}{c}\text { I Solar } \\
\text { Cell } \\
\text { (Ampere) }\end{array}$ \\
\hline The third & 09.00 & 39 & 11.7 & 1,87 \\
day / & 11.00 & 41 & 12.67 & 1,92 \\
scorching & 13.00 & 44 & 13.51 & 1,62 \\
& 15.00 & 40 & 13.2 & 1,84 \\
\hline
\end{tabular}

The solar panel test data on the third day was carried out for 5 hours with an average voltage of 12.8 Volts and a current of $1.8 \mathrm{~A}$.

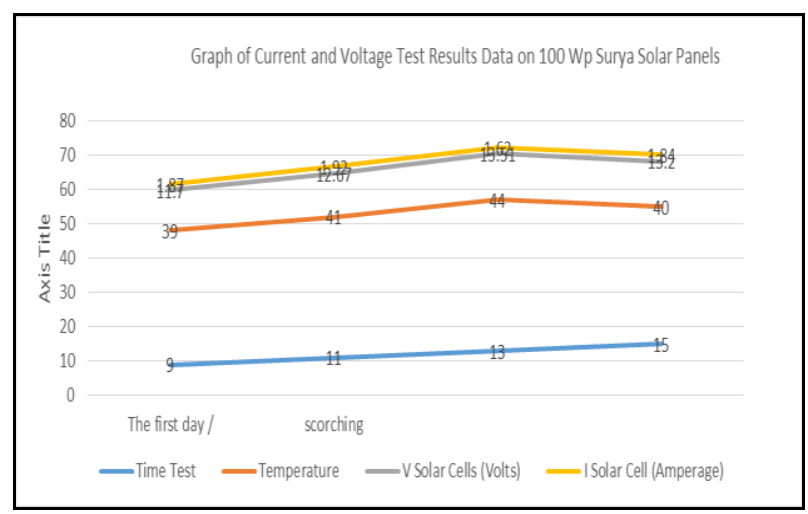

Figure 5. Graph of current and voltage measurement results on solar panel rooftops on the third day

Based on the results of measurements made. Then it can be determined the capacity of the solar panels that will be used by knowing the power requirement of 450 Watt $\times 2=900$ Watt, divided by the length of absorption of solar radiation energy which is for 5 hours.

$(W p)=$ Power Requirement $(\mathrm{Wh})$

$(W p)=900$ Watts $/ 5$ Hours

$(W p)=180 \mathrm{Wp}$
Thus, it can be seen that the number of solar modules needed is 2 units of $180 \mathrm{Wp}$.

Battery capacity $12 \mathrm{~V}, 100 \mathrm{Ah}$

$=12 \mathrm{~V} \times 100 \mathrm{Ah}$

$=1200 \mathrm{Wh}$

$(\mathrm{Jam})=\underline{\text { Battery Capacity }(\mathrm{Wh})}$ Power Requirement (Wh)

$(\mathrm{Jam})=1200(\mathrm{Wh}) / 450(\mathrm{Wh})$

$(\mathrm{Jam})=2.7$ Hours

If the use of 1 battery bears a load of 450 Watts for 2.7 hours, then for users for less than 5 hours, 2 units of $12 \mathrm{~A}, 100 \mathrm{Ah}$ batteries are needed

As for the current capacity of the solar charger controller

$\mathrm{I}_{\mathrm{SCC}}=\mathrm{SCC} \mathrm{x}$ number of batteries

$\mathrm{I}_{\mathrm{SCC}}=6.06 \mathrm{~A} \times 2=12.12 \mathrm{~A}$

While the Inverter To determine the capacity of the inverter must be greater than the total load specified, so based on the total load may be more and not less than the load to be used. The inverter range to be used is from 600 Watt - 1000 Watt. The AC sine wave produced is an imperfect sine wave at the time of measurement or not the same as the sine wave produced by PLN, this is because the character of the inverter used still needs improvement.

\section{Conclusion}

1. Based on the results of research that has been done can be concluded that the rooftop off grid Solar Photovoltaic design and hardware assembly such as solar panel installation that the average voltage and current on the first line is 13 Volts and current is $1.8 \mathrm{~A}$. and on the second day 12.4 Volts and current is $1.6 \mathrm{~A}$ while on the third day of 12.8 Volts and a current of $1.8 \mathrm{~A}$.

2. Condition best when charging the battery from rooftop off grid Solar via solar charge controller at 09.00 WIB until 15.00 WIB. rooftop off grid Solar used has an efficiency of $15 \%$ and $16 \%$ on solar charge controller when charging the battery. On Solar charging from rooftop off grid through the solar charge controller increasingly small current will indicate that the battery will be full and otherwise. Solar module efficiency affect the whole system Solar off grid rooftop performance. Solar off grid rooftop surface 
area affects charging electrical energy in the battery.

\section{Acknowledgements}

This work was supported by the Universitas Muhammadiyah Sumatera Utara and the Institute for Research and Community Service and the Faculty of Engineering.

\section{References}

[1] P. Harahap, "Pengaruh Temperatur Permukaan Panel Surya Terhadap Daya Yang Dihasilkan Dari Berbagai Jenis Sel Surya," RELE (Rekayasa Elektr. dan Energi) J. Tek. Elektro, vol. 2, no. 2, pp. 73-80, 2020, doi: 10.30596/rele.v2i2.4420.

[2] "Energi Terbarukan: Pembangkit Listrik Tenaga Surya Rooftop," pp. 1-4, 2021.

[3] R. Rimbawati, P. Harahap, and K. U. Putra, "Analisis Pengaruh Perubahan Arus Eksitasi Terhadap Karakteristik Generator (Aplikasi Laboratorium Mesin-Mesin Listrik Fakultas Teknik-Umsu)," RELE (Rekayasa Elektr. dan Energi) J. Tek. Elektro, 2019, doi: 10.30596/rele.v2i1.3647.

[4] H. Harmini and T. Nurhayati, "Desain Sistem Rooftop Off Grid Panel Solar Photovoltaic," J. Pengemb. Rekayasa dan Teknol., vol. 13, no. 2, p. 47, 2018, doi: 10.26623/jprt.v13i2.931.

[5] S. Yoomak, T. Patcharoen, and A. Ngaopitakkul, "Performance and economic evaluation of solar rooftop systems in different regions of Thailand," Sustain., vol. 11, no. 23, pp. 1-20, 2019, doi: 10.3390/su11236647.

[6] F. I. Pasaribu and M. Reza, "Rancang Bangun Charging Station Berbasis Arduino Menggunakan Solar Cell 50 WP," R E L E (Rekayasa Elektr. dan Energi) J. Tek. Elektro, vol. 3, no. 2, pp. 46-55, 2021.

[7] P. Harahap, "Implementasi Karakteristik Arus Dan Tegangan Plts Terhadap Peralatan Trainer Energi Baru Terbarukan," Semin. Nas. Tek. UISU, vol. 2, no. 1, pp. 152-157, 2019.

[8] K. Atluri, S. M. Hananya, and B. Navothna, "Performance of Rooftop Solar PV System with Crystalline Solar Cells," 2018 Natl. Power Eng. Conf. NPEC 2018, no. March, pp. $\quad 1-4, \quad 2018, \quad$ doi: 10.1109/NPEC.2018.8476721.
[9] H. P. Indra Viantus(1), A. Hiendro(1), 1, and P. Program Studi Teknik Elektro, UniversitasTanjungpura, "ANALISIS EFISIENSI PADA RANCANG BANGUN SOLAR HOME SYSTEM."

[10] N. Evalina, A. Azis H, Rimbawati, and Cholish, "Efficiency analysis on the inverter using the energy-saving lamp," IOP Conf. Ser. Mater. Sci. Eng., vol. 674, no. $1, \quad 2019$, doi: 10.1088/1757899X/674/1/012034.

\section{Authors' information}

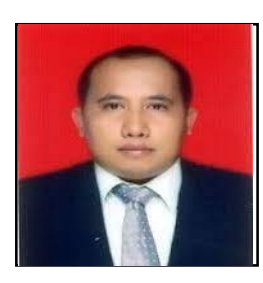

Partaonan Harahap obtained his ST degree in Electrical Engineering from the Muhammadiyah University of North Sumatra, Indonesia in 2005. His Master's Degree in Electrical Engineering was completed in 2015 at the Department of Electrical Engineering, University of North Sumatra, Indonesia. Currently he is a lecturer The Electrical Engineering Department, Universitas Muhammadiyah Sumatera Utara, Indonesia.

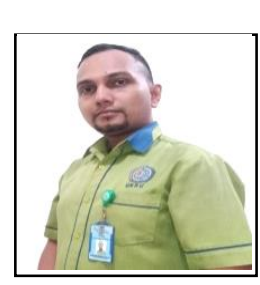

Faisal Irsan Pasaribu obtained an ST degree in Electrical Engineering from the Muhammadiyah University of North Sumatra, Indonesia in 2003. His Masters in Electrical Engineering was completed in 2014 at the Department of Electrical Engineering, University of North Sumatra,Indonesia. Currently he is the head of the Electrical Engineering Study Program and a lecturer in The Electrical Engineering Department, Universitas Muhammadiyah Sumatera Utara, Indonesia.

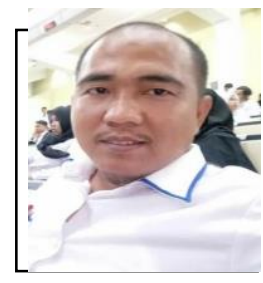

Chandra A. Siregar obtained his ST degree in Mechanical Engineering from the Muhammadiyah University of North Sumatra, Indonesia in 2009. His Masters in Mechanical Engineering was completed in 2017 at the Department of Mechanical Engineering, University of North Sumatra,Indonesia. Currently he is the lecturer in the Mechanical Engineering Department, Universitas Muhammadiyah Sumatera Utara, Indonesia.

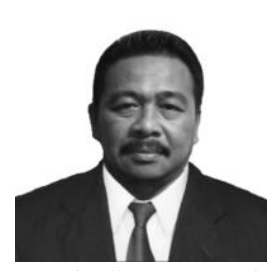

Benny Oktrialdi obtained his ST degree in Electrical Engineering from the Muhammadiyah University of North Sumatra, Indonesia in 1988. His Masters in Electrical Engineering was completed in 2021 at the Department of Electrical Engineering, University of North Sumatra,Indonesia. Currently he is a lecturer in the Electrical Engineering Department, Universitas Muhammadiyah Sumatera Utara, Indonesia. 